\title{
39
}

\section{Tägliche Nervensägen 2 (Hälftenrätsel)}

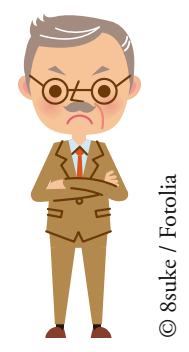

Dein Prof ist einfach unerträglich? Die lieben Lehrämtler stellen endlos viele Baby-Fragen? Dein Laborkollege schmeichelt sich unentwegt beim Chef ein?

Entdecke für deine täglichen Quälgeister (Art-)Namen, an die du ab sofort genüsslich denken wirst, wenn mal wieder jemand deinen wohlverdienten studentischen Frieden stört. Verbinde dazu je zwei Tabletten-Hälften miteinander und bastle besonders bittere Pillen - mentale Pillen, es soll ja niemand beleidigt werden. :-)

Diese fünf Artnamen gibt es tatsächlich. Viel Vergnügen!

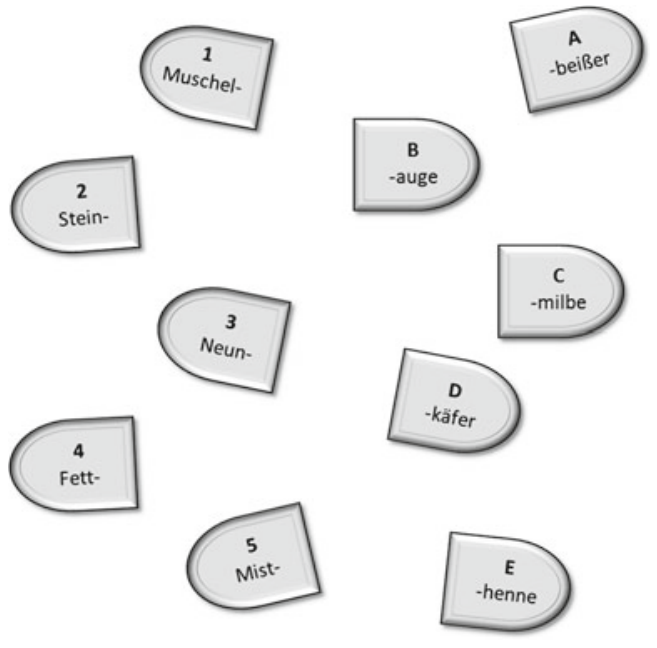

- Feedback und alternative Zweitnamen gerne an: springerraetsel@yahoo.com. 